\title{
ENERGY AND SUSTAINABLE PERFORMANCE OF A MULTIFUNCTIONAL FAÇADE
}

\author{
INÊS SIMÕES ${ }^{1}$, NUNO SIMÕES ${ }^{1,2}$, INÊS SANTOS ${ }^{1}$, MICHAEL BRETT $^{1}$, \\ SÉRGIO TADEU ${ }^{1} \&$ HÉLDER SILVA ${ }^{3}$ \\ ${ }^{1}$ ITeCons - Instituto de Investigação e Desenvolvimento Tecnológico para a Construção, Energia, Ambiente e \\ Sustentabilidade, Portugal \\ ${ }^{2}$ Department of Civil Engineering, Faculty of Sciences and Technology of the University of Coimbra, Portugal \\ ${ }^{3}$ Silva \& Ventura, Lda., Portugal
}

\begin{abstract}
Concerns about increasing comfort levels, reducing energy consumption, reducing waste and using natural, recyclable and reusable products is forcing the construction industry to invest in research and the development of innovative solutions that address these goals. There is still a great market demand for having glazing architectural solutions without neglecting all the other functional characteristics. In this context, a sustainable kit solution for façades was developed, consisting of a modular system that allows the combination of several functionalities and configurations. The system integrates the use of expanded cork (Insulation Cork Boards - ICB) and photovoltaic (PV) glass fastened to the support structure (wall) using an innovative fixation system which allows the disuse of frame profiles, resulting in façades with an elegant appearance. This system feature has both architectural and technical integration advantages. The first part of the paper presents the system's physical behaviour when subjected to real climate conditions. The study was performed on a prototype installed and monitored in the central region of Portugal. In addition, and to better quantify the benefits of having a solution that combines a low thermal resistance envelope using natural thermal insulation and PV energy production, a life cycle of the full solution is performed.
\end{abstract}

Keywords: photovoltaic façade, PV's energy production, life cycle.

\section{INTRODUCTION}

The buildings sector, in the European Union, currently accounts for approximately $40 \%$ of final energy consumption and therefore a significant proportion of total $\mathrm{CO}_{2}$ emissions. This percentage has been increasing, surpassing industry and transport [1]. Following the commitments made under the Kyoto Protocol, a set of policies and measures have been established by the EU, including improving the energy performance of buildings (Directive 2002/91/EC [2] and Directive 2010/31/EU [3]).

To reach this goal, it is necessary to improve the thermal behaviour of a buildings envelope, setting appropriate energy performance requirements for technical building systems, for future buildings and in the requalification of existing buildings [4]. In addition, the concept of Nearly Zero Energy Buildings (NZEB), which is now seen as a realistic solution for reducing energy consumption and $\mathrm{CO} 2$ emissions, has to be considered [5]. Therefore, it is imperative to promote energy efficiency using new constructive technologies, which contribute to the limitation of energy consumption and which are additionally environmentally sustainable due to their material and production processes. This new reality requires the introduction of a "holistic design" that combines different components and technologies in a building through an integrated approach, to the detriment of a traditional dispersed approach of specific or individual elements [6] and that takes into account the whole life cycle. The life-cycle analysis (LCA) is a fundamental tool in the decision-making process for reducing environmental impact, since it focuses on assessing the environmental effect of the processes or products and can be applied successfully at different scales [7]. 
The concept of "Almost Zero Energy" in buildings makes evident the increasing importance of the surrounding energy performance. To the classical principles of the "skin" conception of the buildings of Utilitas (function), Firmitas (solidity, construction) and Venustas (beauty, form) [8], adds the principle of Energy. In fact, the "skin" or envelope of the building has an important function in the energetic balance of the building, because this element is a boundary where the external energy interacts with the inner environment [9]. As such, the promotion of the energetic efficiency of the building's envelope involves the use of "passive" constructive technologies (for instance, externally insulated application solutions), and "active" solutions (for example, energy from renewable energies) [6]. One of the latest lines of envelope development is the integration of multiple façade functions. The trend will be to integrate not only windows, solar protection and other passive devices, but also active systems such as cabling infrastructure, lighting, decentralized air conditioning systems, automatic solar protection, photovoltaic cells, and others. The integration of active and passive systems into multifunctional façades opens a new chapter of potential capital gains that guides the energy efficiency of buildings to a new era [10]. Looking at the different categories of multifunctional façades, it is necessary to emphasize the energy collector façade, which can aggregate, for example, the functions of climate protection, passive solar capture, natural light capture, reception and pre-air conditioning of new air, with an additional function of active energy production, namely using solar thermal collectors or photovoltaic cells.

It is in this context that this article presents a façade solution with thermal and energetic characteristics, optimised according to the climatic requirements of different locations in the European territory, incorporating a cork insulation layer (ICB) and a hidden interface of photovoltaic glass fixation to the wall.

The system development included numerical simulations that were carried out to assess the performance of the solution in different locations. This development took into account the life cycle analysis in a comparative way (with competitive reference solutions) of the system. In order to demonstrate the energy efficiency of the solution, real-time monitoring of a large-scale prototype was carried out. These results are presented below.

\section{SYSTEM DESCRIPTION}

The developed solution is a sustainable kit solution for façades which consists in a modular system that is able to perform multiple functions and present multiple configurations. The system integrates insulation Cork Boards - ICB and photovoltaic (PV) glass fastened to the support structure (wall) using an innovative fixing system which will allow the disuse of frame profiles, resulting in façades with an elegant appearance (slimframe) (Fig. 1). The system uses wire ropes for a fast and easy application.

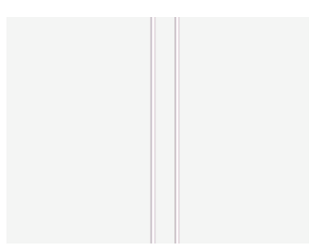

(a)

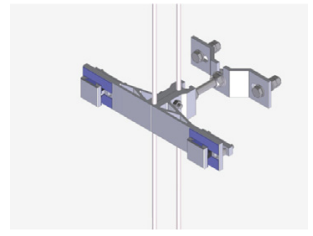

(b)

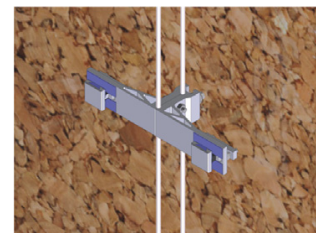

(c)

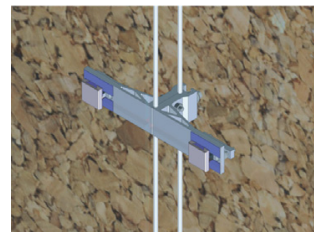

(d)

Figure 1: 3D drawing with the assembly sequence of the system. (a) Cable (wire rope) alignment; (b) Installation of the fastening system; (c) Application of insulation cork boards; and (d) Installation of the glasses. 
This system was designed to be applied on buildings up to $30 \mathrm{~m}$ high and is suitable for new and rehabilitation projects. The fastening system enables a quick assembly system and allows the easy replacement of glasses.

Some laboratory tests were carried out in order to assess the mechanical performance of the system, such as resistance to wind load test, air permeability test and water-tightness test. After that, the system's energetic behaviour when subjected to real climate conditions was evaluated using a prototype installed and monitored in the central region of Portugal. In addition, and in order to quantify the other benefits of the solution, a life cycle and economic assessment of the full solution was also performed. These results are presented below.

\section{REAL ENERGY PRODUTION OF THE SYSTEAM}

After the development of the system, a large-scale test specimen was constructed, using the following elements:

- 15 semitransparency photovoltaic panels (10\% of transparency), with amorphous silicon cells. The dimension of each panel was $1245 \times 635 \mathrm{~mm} 2$;

- air chamber of $30 \mathrm{~mm}$;

- $40 \mathrm{~mm}$ thick insulation Cork Boards;

- air chamber of $100 \mathrm{~mm}$;

- $18 \mathrm{~mm}$ thick wooden board.

The test specimen was subjected to real climatic conditions (Fig. 2). The system was placed in order for the photovoltaic panels to have south orientation. A ventilation system was placed at the top end of the rear side of the wall. This system is activated when the temperature between the system air chamber and the ambient temperature is equal to or greater than $15^{\circ} \mathrm{C}$.

The system is being monitored so as to register the temperatures (at several locations), the solar energy production and the period in which the ventilation is activated. Fig. 3 shows the location of the thermocouples and ventilation system. The system has been monitored since 3rd March.

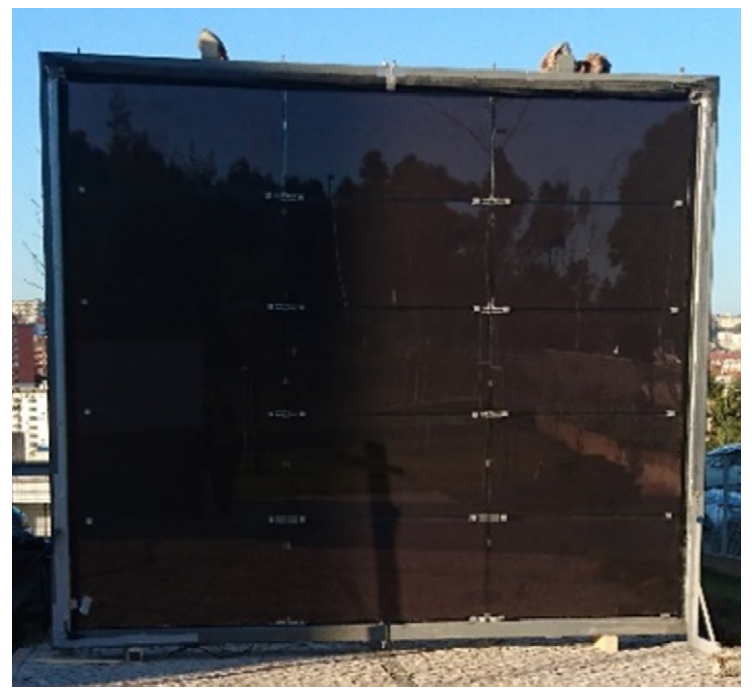

Figure 2: Test specimen. 

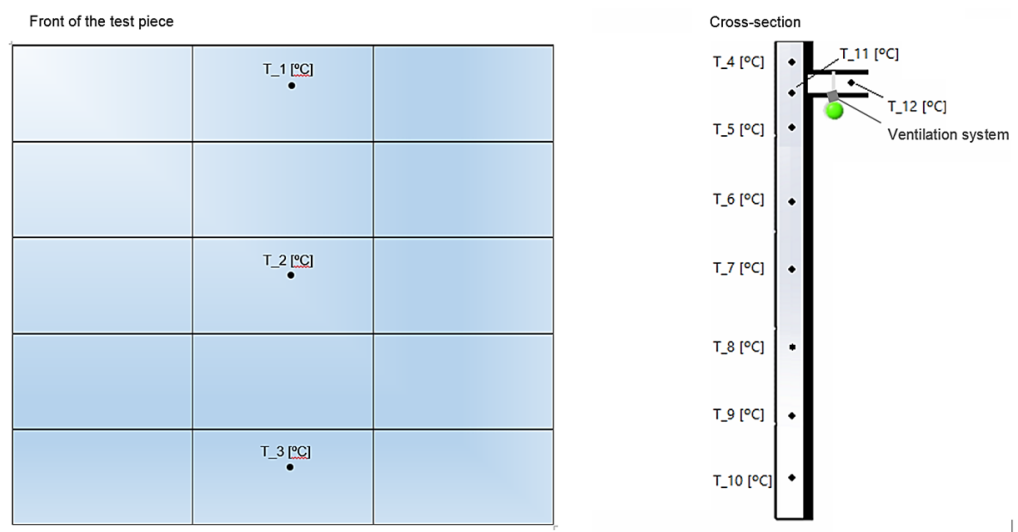

Figure 3: Drawing of the test specimen with the location of the thermocouples and ventilation system.

Fig. 4 shows the results obtained during a period of two weeks of measurement: one week unfavourable to photovoltaic systems and another week of clear days. It is observed that the ambient temperature was similar to the temperature at the base of the air box of the system. This figure shows that the ambient temperature was close to the temperature at the base of the air chamber (thermocouple $T_{-} 10$ ). The temperature difference between the base and top of the air chamber was, sometimes, greater than $20^{\circ} \mathrm{C}$.

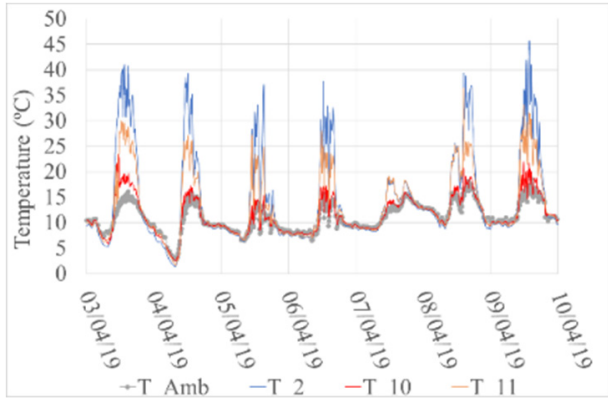

(a)

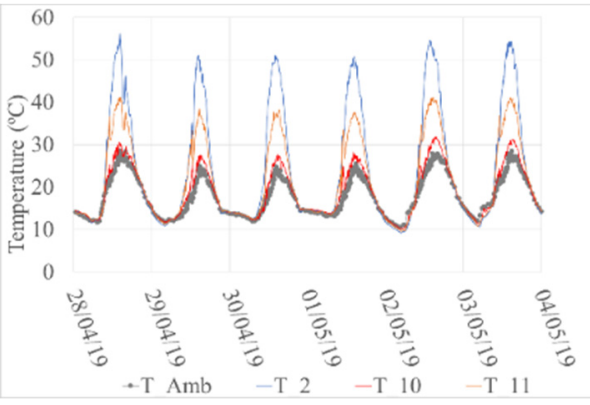

(b)

Figure 4: Experimental results. (a) Unfavourable week to photovoltaic systems: 3rd-10th April; and (b) Favourable week to photovoltaic systems: 28th April-4th May.

Fig. 5 presents the temperature at the top of air chamber, the ambient temperature and power generation on 7th and 28th April, while Fig. 6 presents the power generation with solar radiation, on these days. The 7th April was a cold and cloudy day. On that day, the ventilation system did not switch on during the whole day. The power generation was approximately $3.64 \mathrm{Wh} /$ panel $(4.53 \mathrm{Wh} / \mathrm{m} 2)$. The 28th May was a clear sky day (Fig. 5). The ventilation system was on for more than $12 \mathrm{~h}$. The system produced about $163 \mathrm{Wh} /$ panel $(206.9 \mathrm{Wh} / \mathrm{m} 2)$. If we assume that all PV panels produce the same and also that every day of a month has the same energy production, in one month the system generated about $76 \mathrm{kWh}$. This value is higher than the simulated using numerical models. 


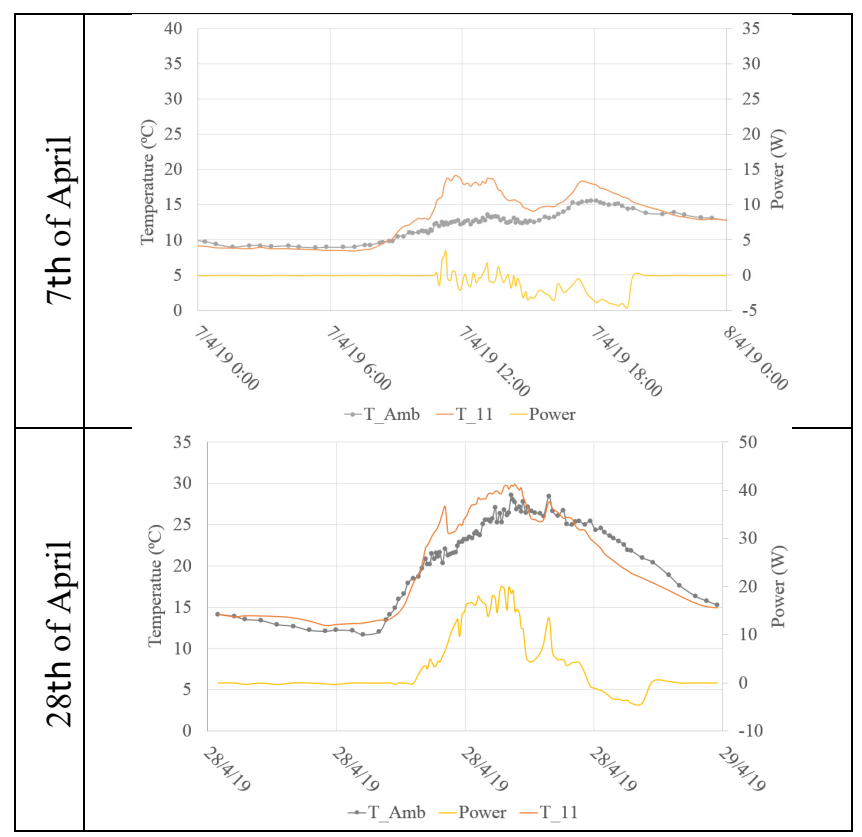

Figure 5: Experimental results on 7th and 28th of April: temperature and power generation.

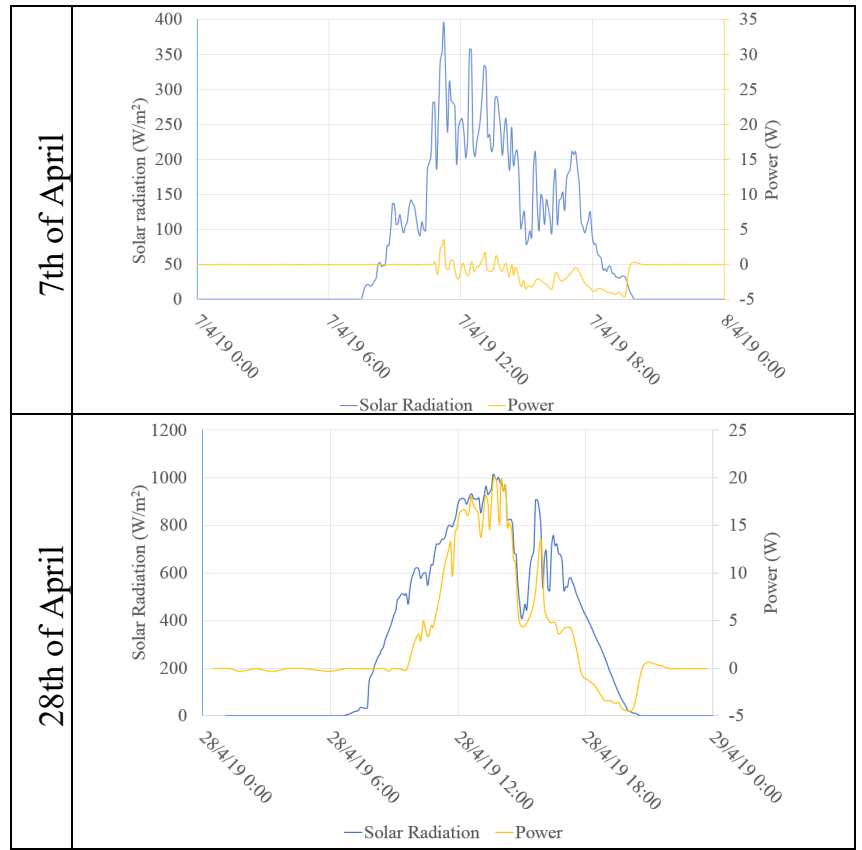

Figure 6: Experimental results on 7th and 28th of April: power generation and solar radiation. 


\section{LIFE CYCLE ANALYSIS}

The innovation of this construction system is the fastening system. However, it is in our interest to characterise the performance of the system as a whole. For this reason, at a first stage, only the life cycle of the fixation system was analysed, and at a second stage, it was extended to the system as a whole.

\subsection{Life cycle analysis}

The life cycle analysis (LCA) had the objective of quantifying the environmental performance of the multifunctional façade system integrating cork and photovoltaic system with occult fixation developed and described above, as well as to identify the elements of inventory with greater contribution to the different categories of impact. The study was divided into two parts:

1. The product stage of the innovative fixation system (\#PFSlim) was analysed, and its performance was compared with that of a conventional spider fixation (\#PFConv) - Fig. 7;

2. The façade system, including the innovative fixation, was analysed, taking into account three variations in the glass unit: (2.1) façade system without photovoltaic (\#SFSPV); (2.2) façade system with photovoltaic 4\% transparency (\#SFPV4\%); (2.3) façade system with photovoltaic 10\% transparency (\#SFPV10\%). Additionally, three building locations were considered (case 1: Munich, case 2 Oslo, and case 3: Lisbon).

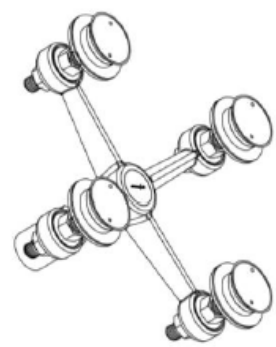

(a)

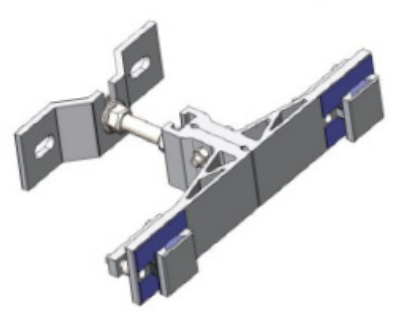

(c)

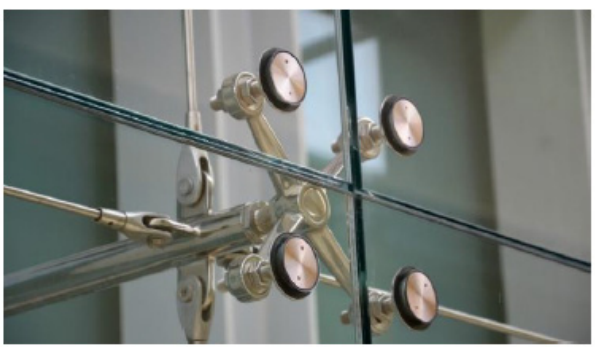

(b)

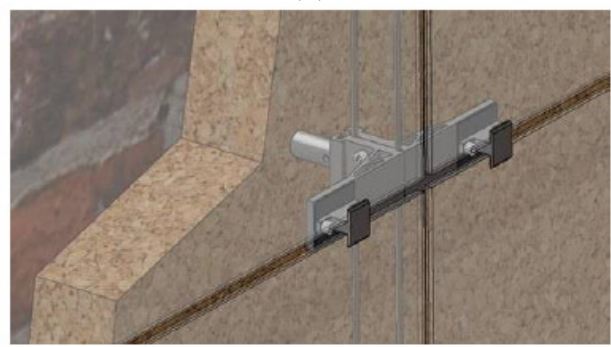

(d)

Figure 7: The fixation system study. (a) Conventional spider fixation; (b) Example of a façade system incorporating a conventional spider fixation; (c) Innovative fixation system; and (d) Representation of a façade system incorporating the innovative fixation system. 
The development of the lifecycle model of the innovative fixation system took into account the stages of extraction and processing of raw materials, transport and production of the components. The LCA study of the façade system took into account the stages of extraction and processing of raw materials, transportation, component production, construction of façade systems and a scenario of use, namely electric energy production and heating/cooling needs. A façade system with capacity to produce electricity through photovoltaic panels is a multifunctional system. According to standard ISO 14044:2006/Amd1:2017, for multifunctional systems, the allocation of environmental loads should be avoided by dividing the system into two or more processes or by expanding the boundaries of the system. In this study, to evaluate the benefits of producing and using solar energy it was necessary to expand the system boundaries, through the approach of avoided burdens. In this regard, it was considered that the production of solar energy replaces the electricity production of the grid, being equivalent. In this way, the production of solar energy is assumed as credit in the impacts of the life cycle analysis of the façade systems. The functional unit is $1 \mathrm{~m}^{2}$ of multifunctional façade, including cork, glass and the fixation system, with a reference life of 30 years.

\subsection{Analysis methodology}

The study presented here uses the methodology of the life cycle analysis based on international standards ISO 14040:2006 and ISO 14044:2006/Amd1:2017. This methodology allows the quantification and evaluation of potential environmental impacts throughout the life cycle of a product, from the extraction of the raw materials to the end of its life, through the compilation of inflows and outflows (mass and energy flows). The CML-IA version 4.2 (Leiden University, April 2013) with a midpoint approach, was used for the evaluation of life-cycle impacts (LCIA). The following impact categories were considered: Abiotic Depletion - elements (ADP - elements), Abiotic Depletion - Fossil Resources (ADP - fossil resources), Global Warming (GWP), Ozone Layer Depletion (ODP), Photochemical Oxidation (POCP), Acidification of Water Resources and Soil (AP), Eutrophication (EP).

In this study, all data concerning the real production of fastening parts and façade systems were considered. The grid electricity production, considered in the usage scenario, was determined based on the Portuguese, Germany and Norway's production mix in 2014 (Electricity low voltage), available in the Ecoinvent v3.4 database. The inventory data are in accordance with the quantities used in the production of fasteners, in the production of photovoltaic panels, in the construction of the prototype and in the calculation of a use scenario. To complement missing data or to compare and validate existing data, we also used bibliographic sources and the Ecoinvent v 3.4 database.

\subsection{Studied scenarios}

The heating/cooling needs and the production of solar energy used in this study were published by Melo [11], obtained for a service building with an interior area of $20 \mathrm{~m}^{2}$, which integrates a façade of $12 \mathrm{~m}^{2} .80 \%$ of this façade is glazing (PAE $\left.=80 \%\right)$. In this stage, the energy consumption was considered to meet the heating and cooling needs of the building for 30 years, as well as the production of solar energy by the photovoltaic system (when applicable). Table 1 resume the annual energy flows for the façade systems and localities under analysis. 
Table 1: Annual energy flows for the façade systems and localities.

\begin{tabular}{|l|c|c|c|}
\hline & \#SFSPV & \#SFPV4\% & \#SFPV10\% \\
\hline Case 1: Munich & & & \\
\hline Cooling energy requirements (kWh/year) & 210 & 0 & 60 \\
\hline Heating energy needs (kWh/year) & 815 & 1050 & 915 \\
\hline Production of solar energy (kWh/year) & 0 & 80 & 55 \\
\hline Case 2: Oslo & & & \\
\hline Cooling energy requirements (kWh/year) & 125 & 0 & 25 \\
\hline Heating energy needs (kWh/year) & 1100 & 1290 & 1190 \\
\hline Production of solar energy (kWh/year) & 0 & 60 & 45 \\
\hline Case 3: Lisbon & & & \\
\hline Cooling energy requirements (kWh/year) & 1010 & 220 & 500 \\
\hline Heating energy needs (kWh/year) & 80 & 95 & 100 \\
\hline Production of solar energy (kWh/year) & 0 & 150 & 110 \\
\hline
\end{tabular}

\subsection{Results}

Fig. 8 shows the comparative environmental assessment of the product step of the fixation system. The results show that the \#PFConv fastening have the worst performance for all impact categories, which is due to the use of stainless steel in most of the components and because of the use of material in greater quantity.

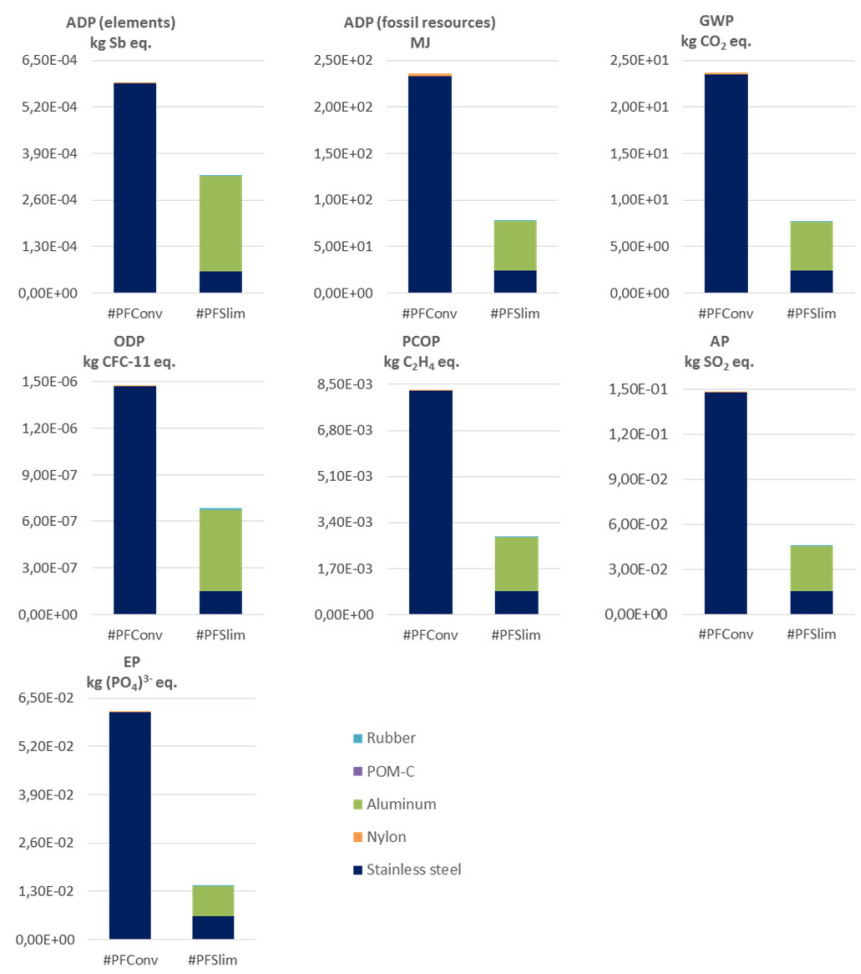

Figure 8: Environmental assessment of the product step of the fixation system. 
Fig. 9 presents a comparative environmental assessment of the product stage of façade systems \#SFSPV, \# SFPV4\% and \# SFPV10\%, for the environmental impact categories under analysis. It was observed that for the façade system \#SFPV4\% and \#SFPV10\%, the photovoltaic panels presented greater contribution to all the impact categories. This is because the production process of photovoltaic panels uses raw materials with a significant environment impact (mainly due to the lass, photovoltaic cells and encapsulation, which representing between 41.9 and $76.6 \%$ of the impacts). For this reason, the comparative evaluation between the façade systems shows that the \#SFPV4\% system performs worse in all impact categories, due to the productive process of the photovoltaic panels.

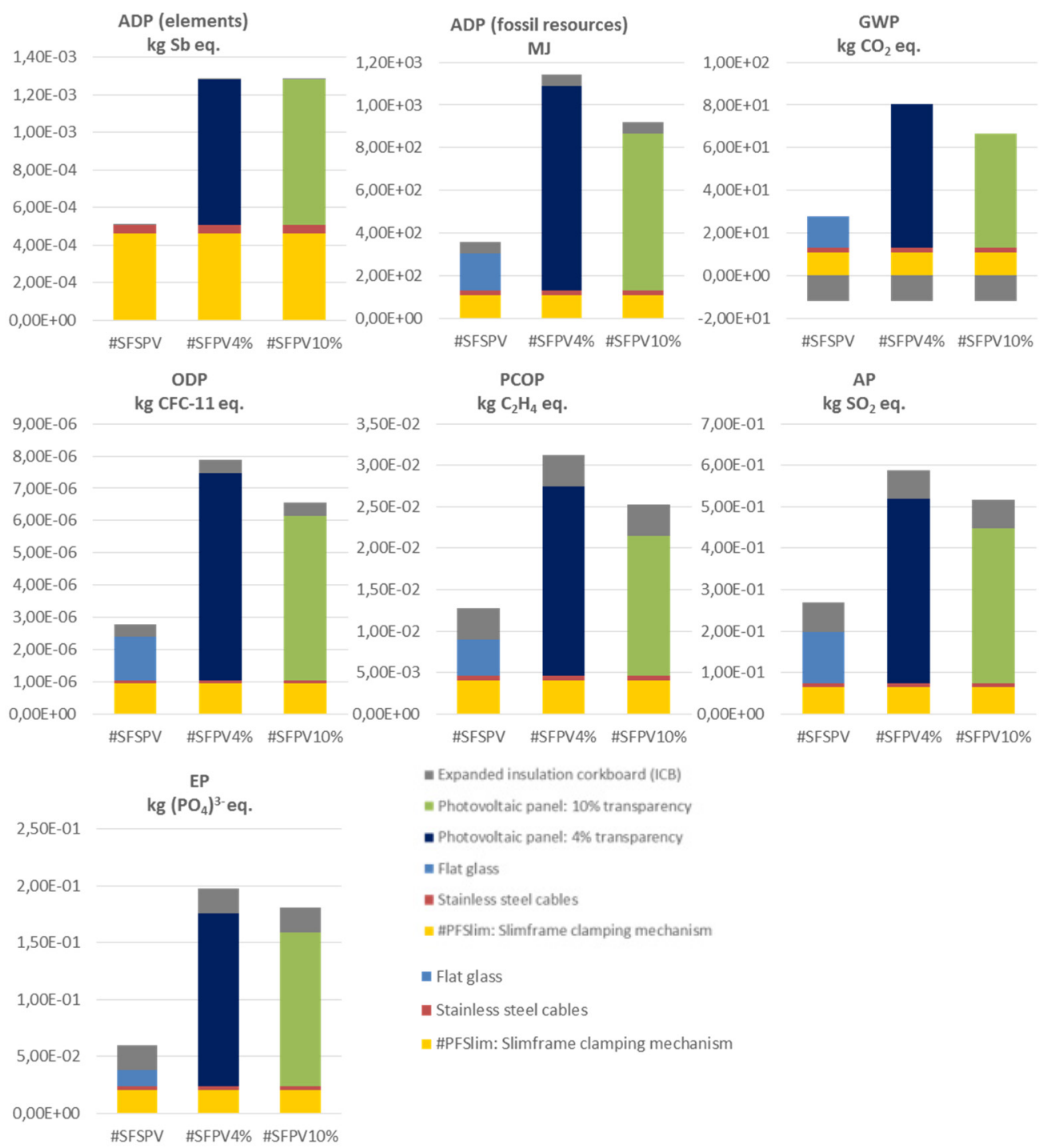

Figure 9: Comparative environmental assessment of the product stage of façade systems for the environmental impact categories under analysis. 
Fig. 10 shows a comparative environmental assessment of each stage of life cycle and use scenario of façade systems under analysis and avoided impacts. The comparative evaluation shows that the location in Oslo presents better performance for all categories of impact, except for the OPD category, which is due to the energy mix of this country being composed by a large percentage of renewable energy. On the other hand, Munich's location exhibits the worst performance for all impact categories, except for the POCP category, which is due to the energy mix of this country being composed of a large percentage of non-renewable energy (e.g. coal), thus increasing impacts on the use stage. For Lisbon's location, the façade system \#SFPV4\% shows the best performance for all categories, except for the category ADP (elements), because this city is located in the Mediterranean, with mild winters, summers warmer and more sun exposed.

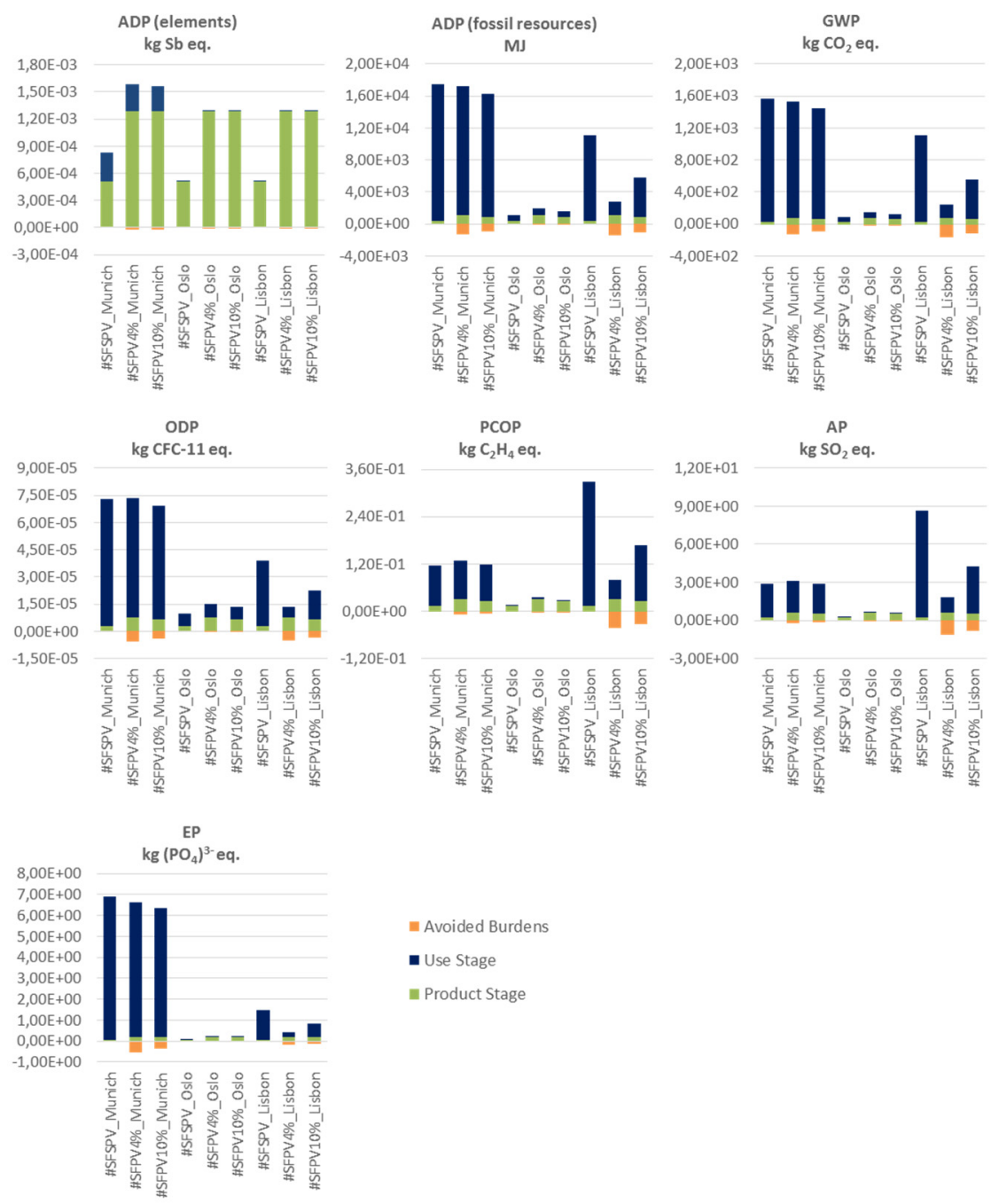

Figure 10: Comparative environmental assessment of each stage of life cycle and use cases of façade systems under analysis and avoided impacts. 
It should be noted that in the use stage of the \#SFPV10\% and \# SFPV4\% façades, impact was avoided due to the replacement of the electric power of the grid by solar electric energy in the heating / cooling of the building.

The highest percentage of impact avoided was in Lisbon, because it was the city which had the highest production of solar energy.

\section{CONCLUSION}

This article presents a façade solution with thermal and energetic characteristics, optimised according to the climatic requirements of different locations in the European space, incorporating a cork insulation layer (ICB) and a hidden interface of photovoltaic glass fixation to the wall.

After system development, a real test specimen was placed outside a building and subjected to real climatic conditions. This system was monitored to monitor the temperatures and the energy production. The results show that the energy production was similar or even better than those obtained in the numerical simulation.

The life cycle analysis of the system was presented in a comparative way, and the results have confirmed environmental benefits.

\section{ACKNOWLEDGEMENT}

This work was framed within the CENTRO-01-0247-FEDER-033896 (S\&V SunRoof) Project funded by Portugal 2020 through the COMPETE 2020.

\section{REFERENCES}

[1] Pérez-Lombard, L., Ortiz, J. \& Pout, C., A review on buildings energy consumption information. Energy and Buildings, 40(3), pp. 394-398, 2008.

[2] E. Commission e C. Document, Directive 2002/91/EC of the European Parliament and of the Council of 16 December 2002 on the energy performance of buildings, Off. J. Eur. Union, pp. 65-71, 2002.

[3] E. Commission e C. Document, Directive 2010/31/EU of the European Parliament and of the Council of 19 May 2010 on the energy performance of buildings, Off. J. Eur. Union, pp. 13-35, 2010.

[4] Ascione, F., De Rossi, F. \& Vanoli, G.P., Energy retrofit of historical buildings: Theoretical and experimental investigations for the modelling of reliable performance scenarios. Energy and Buildings, 43(8), pp. 1925-1936, 2011.

[5] Marszal, A.J. et al., Zero Energy Building - A review of definitions and calculation methodologies. Energy and Buildings, 43(4), pp. 971-979, 2011.

[6] World Business Council for Sustainable Development (WBCSD), Energy Efficiency in Buildings Facts \& Trends - Full report, 2008.

[7] Ortiz, O., Castells, F. \& Sonnemann, G., Sustainability in the construction industry: A review of recent developments based on LCA. Construction and Building Materials, 23(1), pp. 28-39, 2009.

[8] Vitruvio Pollio, M., Vitrúvio - Tratado de Arquitectura, Lisboa: IST Press, 2006.

[9] Bradshaw, V., Building control systems. New York: John Wiley and Sons, Inc., 1993.

[10] Castrillón, R.D.A., Integration of Active and Passive Systems in Glass Façades. Presented at 8th International Conference on Sustainable Energy Technologies, Aachen, Germany, pp. 1-8, 2009.

[11] Melo, L., Avaliação de desempenho de um sistema passivo de aquecimento integrando vidro fotovoltaico, 2016. 